\title{
Age and geochemistry of the Boucaut Volcanics in the Neoproterozoic Adelaide Rift Complex, South Australia
}

Sheree E Armistead*1,2,3, Alan S Collins ${ }^{1}$, Solomon Buckman ${ }^{4}$ and Rachel Atkins ${ }^{1}$

${ }^{1}$ Tectonics and Earth Systems (TES) Group and the Mineral Exploration CRC, Department of Earth Sciences, The University of Adelaide, SA 5005, Australia

${ }^{2}$ Geological Survey of Canada, 601 Booth Street, Ottawa, Ontario, Canada

${ }^{3}$ Metal Earth, Harquail School of Earth Sciences, Laurentian University, Sudbury, Ontario, Canada

${ }^{4}$ School of Earth, Atmospheric and Life Sciences, University of Wollongong, Wollongong Australia

This manuscript is not published and is under review in the Australian Journal of Earth Sciences. Please note that subsequent versions of this manuscript will have slightly different content. If accepted, the final version of this manuscript will be available via the 'Peer-reviewed Publication DOI' link on the right-hand side of this webpage.

Please feel free to contact the corresponding author, we welcome your feedback!

*corresponding author email: sarmistead@laurentian.ca

Keywords: Adelaide Rift Complex, Flinders Ranges, Geochemistry, Geochronology, Neoproterozoic, Rodinia, Snowball Earth, Adelaide Superbasin 


\section{ABSTRACT}

2 The Adelaide Rift Complex in South Australia records the break-up of Rodinia at a time of great

3 climatic and biological evolution. The Boucaut Volcanics within the Neoproterozoic Adelaide Rift

4 Complex of the Adelaide Superbasin lie at the base of the Burra Group, marking the boundary

5 between the Burra Group and underlying Callanna Group. Despite their significance as one of

6 the few volcanic units within the rift complex, there has been no robust age determination

7 published for the Boucaut Volcanics. We use U-Pb zircon LA-ICP-MS data to determine an age

8 of $788 \pm 6 \mathrm{Ma}$ for the eruption of the bimodal Boucaut Volcanics. This has important implications

9 for constraining the timing of stratigraphy within the Adelaide Superbasin. This also has far

10 reaching implications for plate tectonic reconstructions of Australia and Laurentia, and for

11 correlating global isotope anomalies for the Neoproterozoic.

\section{INTRODUCTION}

13 The Adelaide Superbasin in South Australia preserves Tonian to Middle Cambrian sedimentary

14 and minor volcanic rocks (Lloyd et al., 2020; Preiss, 2000). They preserve some of the best

15 evidence for the evolving, and sometimes tumultuous, events that characterise this time in

16 Earth's climatic, biological and geological systems. For example, the earliest known complex

17 multicellular lifeforms are preserved within the Ediacara Hills of the Flinders Ranges, and

18 extensive tillites provide evidence for Earth's global Cryogenian glaciation events (Hoffman et

19 al., 2017; Le Heron, Cox, Trundley, \& Collins, 2011). Of significance to paleogeographic

20 reconstructions, the Adelaide Rift Complex also contains rocks that have been interpreted as

21 forming during the breakup of supercontinent Rodinia (Merdith, Collins, et al., 2017; Powell,

22 Preiss, Gatehouse, Krapez, \& Li, 1994; Preiss, 2000) (Figure 1). Understanding the tectonic and 
23 geological evolution of the Adelaide Rift Complex underpins our understanding of these

24 significant Neoproterozoic events, not only in Australia, but globally.

25 One of the major challenges in reconstructing the evolution of the Adelaide Superbasin, is the

26 lack of datable volcanic units and/or fossil assemblages that can provide quantitative age

27 constraints on rifting and sedimentation. These challenges limit our ability to confidently

28 correlate sequences in the Adelaide Superbasin with those in other regions.

\section{$29 \quad 1.1 \quad$ Tectonic overview}

30 The Neoproterozoic to middle Cambrian stratigraphy within the Adelaide Rift Complex formed

31 during at least five major successive rift cycles that led to the breakup of supercontinent Rodinia

32 (Preiss, 2000). In the Adelaide Rift Complex, initiation of the breakup of Rodinia is marked by

33 the $827 \pm 6$ Ma Gairdner Dyke Swarm (Wingate, Campbell, Compston, \& Gibson, 1998), which

34 is interpreted to be coeval with the poorly dated Wooltana Volcanics (Compston, Crawford, \&

35 Bofinger, 1966). The second phase of rifting in the Adelaide Rift Complex is marked by the 802

$36 \pm 10$ Ma Rook Tuff within the Callanna Group (pers. comm. Fanning 1994 in Preiss 2000). The

37 third phase of rifting is marked by the Boucaut Volcanics. This rift phase marks the beginning of

38 extensive syn-rift facies within the Adelaide Superbasin, yet, it has resisted attempts at dating

39 and forms the focus of this study.

40 According to both the SWEAT (south-west US - East Antarctica; Dalziel, 1991; Moores, 1991)

41 and AUSWUS (Australia-Western US; Burrett and Berry, 2000) hypotheses, the Laurentian and

42 East Antarctic-Australian cratons were contiguous during the late Neoproterozoic. This has led

43 to attempted correlations between the stratigraphy of the Adelaide Superbasin and western

44 Laurentia. The SWEAT hypothesis posits a close link between southern Australia and NW 
45 Canada. In this configuration the Boucaut Volcanics have been linked with the Little Dal Group

46 of the Mackenzie Mountains in the Yukon-Northwest Territories of Canada (Milton, Hickey,

47 Gleeson, \& Friedman, 2017) (Figure 1 SWEAT reconstruction). Alternatively, the AUSWUS fit

48 (Figure 1), the Adelaide Superbasin lies adjacent to south-western US, and correlations with

49 stratigraphy in the Death Valley have been proposed (e.g. Dehler et al., 2017; Mahon et al.,

50 2014). An analysis of kinematic data for the different reconstructions in Figure 1 showed that

51 models that put Australia adjacent to southern Laurentia (e.g. AUSWUS, and a more extreme

52 version with Australia adjacent to Mexico - AUSMEX, Wingate et al. 2002) are the easiest to

53 reconcile with Phanerozoic plate kinematic norms (Merdith, Williams, Müller, \& Collins, 2017).

54 On a smaller scale, correlations between the Adelaide Superbasin and northwest Tasmania

55 have also been proposed, for example, between the c. 790 Ma Black River Dolomite of

56 northwest Tasmania (Calver, 1998) and the Skillogallee Formation of the Adelaide Superbasin.

57 However, more recent detrital provenance studies suggest that Neoproterozoic stratigraphy in

58 Tasmania differs from the Adelaide Superbasin and instead correlate with rocks in the Death

59 Valley in California and the Transantarctic Mountains (Mulder, Berry, Halpin, Meffre, \& Everard, 60 2018).

61 Constraining correlations has important implications for paleogeographic reconstructions of

62 Laurentia-Australia in the Rodinia supercontinent. Unfortunately, many of these correlations rely

63 on old and/or unreliable age data, particularly for the Adelaide Superbasin (Figure 2). 


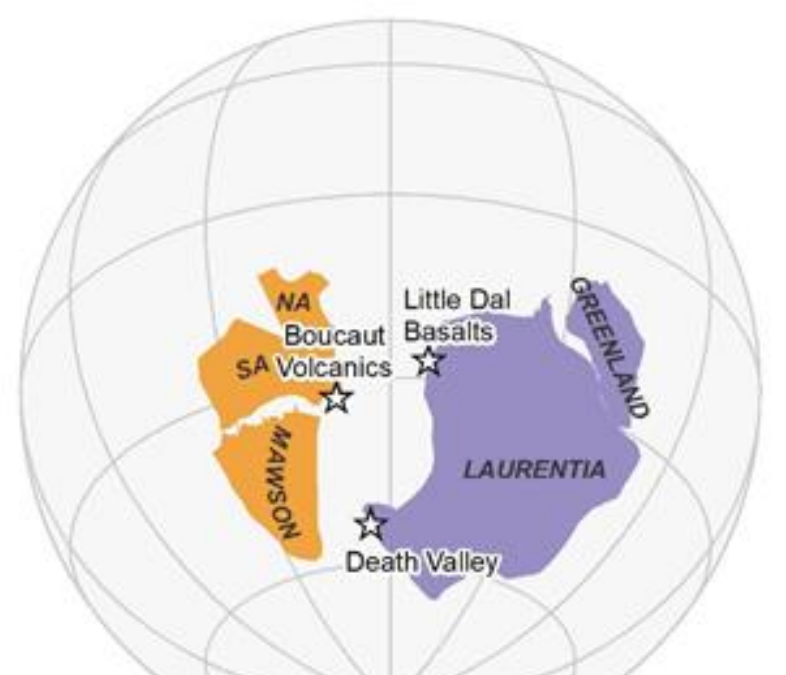

SWEAT

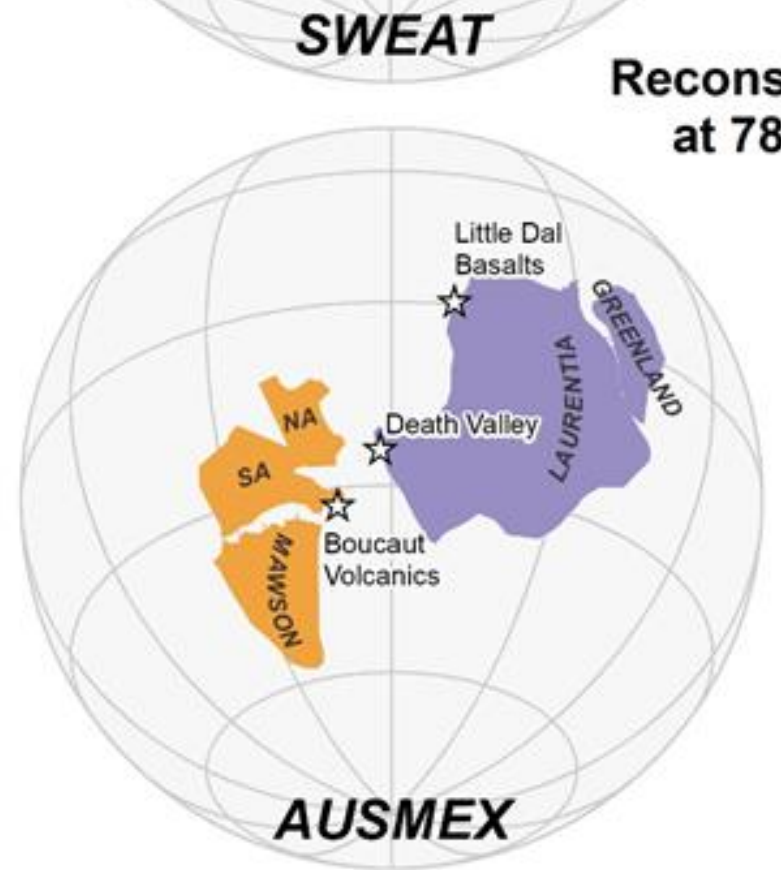

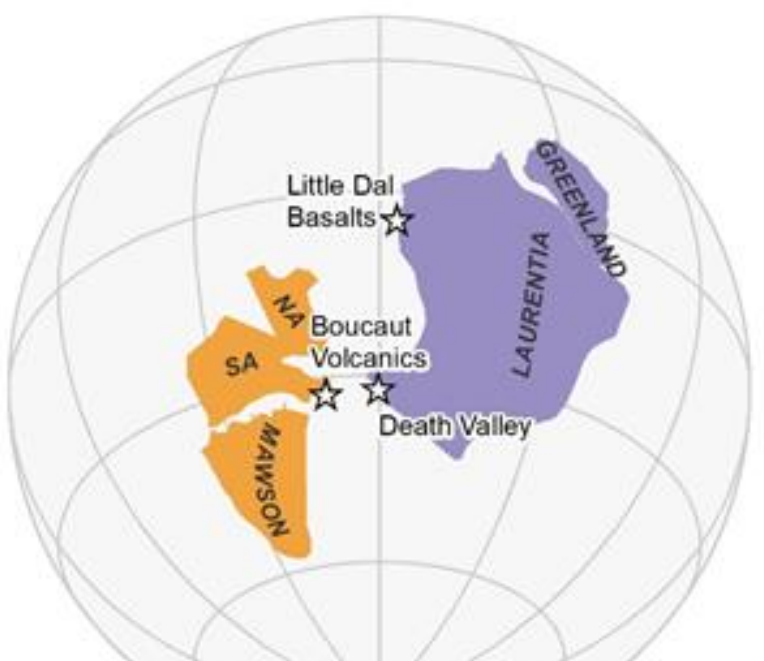

AUSWUS
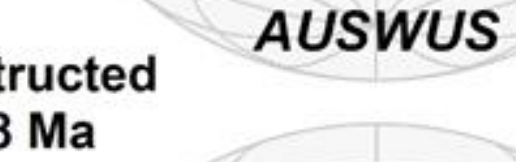

Figure 1: GPlates tectonic reconstructions of the different Australia-Laurentia models at $788 \mathrm{Ma}$ (the crystallisation age of the Boucaut Volcanics), made using the models in Merdith, Williams, et

67 al. (2017). South Australia is fixed in its present-day position with all other blocks rotated relative

68 to it at 788 Ma. SWEAT reconstruction based on Dalziel (1991); Hoffman (1991); Moores (1991).

69 AUSWUS reconstruction based on Karlstrom et al. (1999). AUSMEX reconstruction based on

70 Wingate et al. (2002). Missing Link reconstruction based on Li, Zhang, and Powell (1995). NA =

$71 \quad$ North Australia, SA = South Australia. 


\section{$72 \quad 1.2$ THE BOUCAUT VOLCANICS}

73 The Boucaut Volcanics lie at the base of the Burra Group and provide an important maximum

74 age constraint for this package. They also constrain the maximum age for the underlying

75 Callanna Group. The age of the Boucaut Volcanics has been most widely reported as $777 \pm 7$

$76 \mathrm{Ma}$ (pers. comm. Fanning 1994 in Preiss 2000), however, no isotopic data are published for this

77 associated age. Confusingly, another source (Drexel, Preiss, \& Parker, 1993) mentions that

78 Fanning (1989) derived an upper intercept age of $783 \pm 42$ Ma for the Boucaut Volcanics, but

79 the original source of these data are obscure. Regardless, robust isotopic age determinations

80 are needed to constrain the age of this significant unit.

81 The Boucaut Volcanics are dominated by pale pink to grey rhyolite, with amygdaloidal andesite

82 and basalt also present (Forbes, 1978). These rocks have undergone several phases of

83 deformation and have been metamorphosed to 'biotite grade' (Forbes, 1978). The Boucaut

84 Volcanics occur within the southeastern part of the Nackara Arc, and the majority of outcrops

85 are isolated and many are sheared along the northeast-trending Anabama Shear Zone (Preiss,

86 2000). The Boucaut Volcanics mark a major stage of rifting in the Adelaide Rift Complex that

87 has been interpreted by many as reflecting the separation of Laurentia from Australia and the

88 initiation of the Pacific Ocean basin (Preiss, 2000).

89 In this contribution, we have collected new $\mathrm{U}-\mathrm{Pb}$ zircon data from a rhyolite within the Boucaut

90 Volcanics, to provide a robust age constraint on the timing of eruption. Significantly, this new

91 age constrains the base of the Burra Group and the onset of early rifting within the Adelaide Rift

92 Complex, providing important constraints on plate reconstructions for the breakup of

93 supercontinent Rodinia (e.g. Merdith et al., 2017a; Merdith et al., 2017b). 


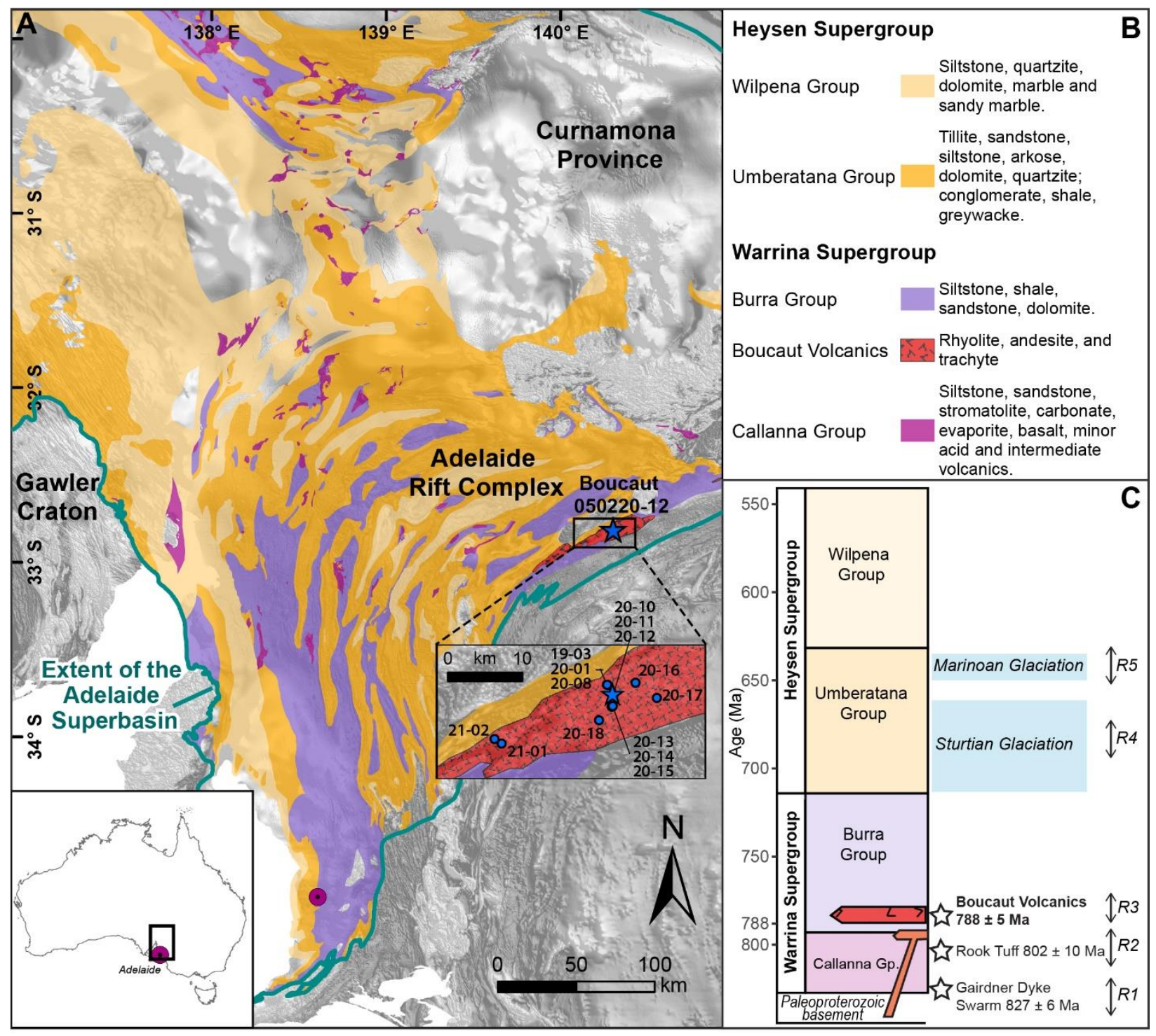

Figure 2: a) Geological map of the Adelaide Superbasin, including the Adelaide Rift Complex, overlying a total magnetic intensity, reduced to the pole image (source: SARIG). Location of geochronology sample indicated by the star (050220-12), whole-rock geochemistry samples indicated by circles in the inset (abbreviated; all samples have prefix 0502-). Extent of the Adelaide Superbasin after Lloyd et al. (2020). Geological polygons from SARIG. Coordinate system: GDA 1994; b) legend for geological map, descriptions for each unit from Australian Stratigraphic Units Database; and c) simplified tectono-stratigraphic history of the Adelaide Superbasin. R1-R5 mark the five major rifting events of the Adelaide Rift Complex. Rook Tuff date from Fanning, Ludwig, Forbes, and Preiss (1986), and Gairdner Dyke Swarm from Wingate et al. (1998). 


\section{ANALYTICAL METHODS}

106

107

108

109

110

111

112

113

114

115

116

117

118

119

120

121

122

\section{3}

124

125

126

\subsection{Zircon U-Pb and trace element geochemistry}

A rhyolite sample from the Boucaut Volcanics (Sample 050220-12) was crushed and separated for zircons. Zircons were hand-picked and mounted in epoxy resin, and then polished and carbon coated. To identify suitable domains for analysis, zircons were imaged using a Gatan cathodoluminescence $(\mathrm{CL})$ detector attached to Quanta 600 MLA Scanning Electron Microscope. Zircon U-Pb isotopic and REE/trace element determination was undertaken at the University of Adelaide using an Agilent 7900x ICP-MS with an attached ASI Resolution excimer 193nm laser ablation system. A spot size of $29 \mu \mathrm{m}$ and frequency of $5 \mathrm{~Hz}$ was used and isotopes ${ }^{90} \mathrm{Zr},{ }^{201} \mathrm{Hg},{ }^{204} \mathrm{~Pb},{ }^{206} \mathrm{~Pb},{ }^{207} \mathrm{~Pb},{ }^{208} \mathrm{~Pb},{ }^{232} \mathrm{Th}$ and ${ }^{238} \mathrm{U}$ were measured. Each analysis comprised a 20 s background and 30 s ablation. GEMOC GJ-1 zircon was used to correct for U$\mathrm{Pb}$ fractionation (TIMS normalising ages ${ }^{207} \mathrm{~Pb} /{ }^{206} \mathrm{~Pb}=607.7 \pm 4.3 \mathrm{Ma},{ }^{206} \mathrm{~Pb} /{ }^{238} \mathrm{U}=600.7 \pm 1.1$ $\mathrm{Ma}$ and ${ }^{207} \mathrm{~Pb} /{ }^{235} \mathrm{U}=602.0 \pm 1.0 \mathrm{Ma}$; Jackson et al. 2004). The Plešovice zircon standard was used to assess accuracy over the course of the laser session (ID TIMS ${ }^{206} \mathrm{~Pb} /{ }^{238} \mathrm{U}=337.13 \pm$ 0.37 Ma; Sláma et al., 2008). Ten Plešovice standard analyses were made and yielded a weighted average ${ }^{206} \mathrm{~Pb} /{ }^{238} \mathrm{U}$ age of $335.2 \pm 4.1 \mathrm{Ma}(2 \sigma ; \mathrm{MSWD}=0.76)$, which is within uncertainty of the ID TIMS age. Data were processed using lolite (Paton, Hellstrom, Paul, Woodhead, \& Hergt, 2011). U-Pb data and REE data are provided in Supplementary A.

\subsection{Whole-rock Geochemistry}

Twenty-one samples from the Boucaut Volcanics were analysed for whole-rock geochemistry (see Figure 2a inset for sample locations). Major element geochemistry was obtained through the analysis of fused glass discs using X-Ray Fluorescence (XRF) at the University of Adelaide. 
127 Trace and rare earth element geochemistry were undertaken by Amdel in Adelaide using IC3M

128 and ICM3R. A subsample of up to $0.5 \mathrm{~g}$ of the analytical pulp was digested using an HF/multi

129 acid digest and the solution was presented to an ICPMS for the quantification of the elements of

130 interest. Geochemistry data are provided in Supplementary A.

\section{RESULTS}

\section{$132 \quad 3.1$ Sample descriptions}

133 The Boucaut Volcanics crop out near Boucaut East Dam, about $79 \mathrm{~km}$ south of Olary (Figure 2).

134 Small isolated outcrops of highly vesicular basalt and rhyolite (Figure 3) are interbedded with

135 thin beds of mudstone and some cross-bedded sandstones indicating a shallow marine

136 environment during deposition of the basal Burra Group. Strain partitioning has resulted in

137 preservation of undeformed pods of volcanics enveloped by strongly foliated equivalents. Minor

138 copper mineralisation is associated with the basalts at Cronje Dam. The rhyolites sampled for

139 this study were relatively fresh, fine-grained, flow-banded rhyolites with small $(<1 \mathrm{~cm})$

140 phenocrysts of quartz and feldspar.

141 Sample descriptions and locations are provided in Table 1 and shown in Figure 2. Basalts were

142 collected from the type section whilst rhyolites were collected from surrounding outcrops on the

143 tops of small hills. Examples of outcrop textures are shown in Figure 3. 


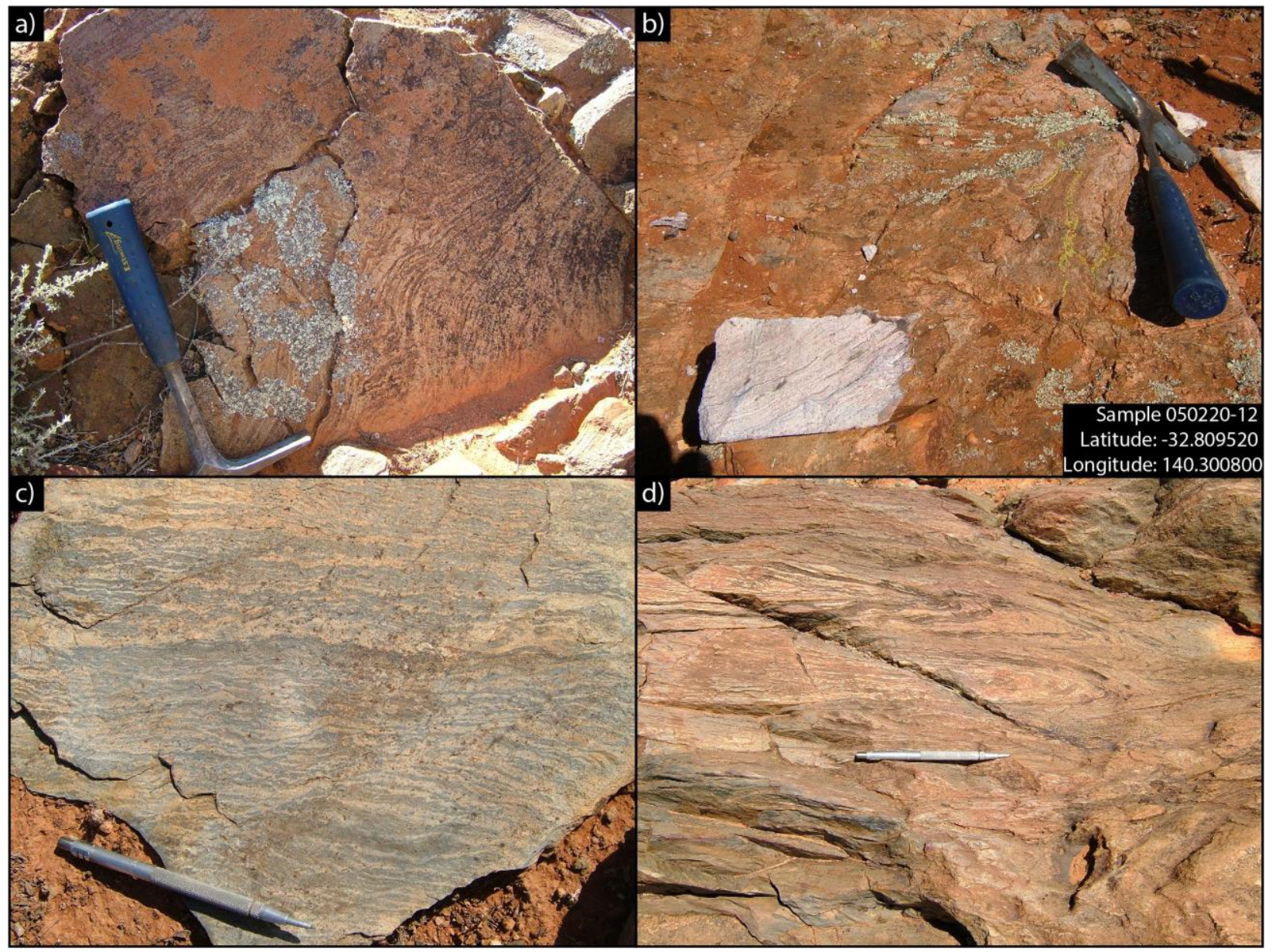

146 Figure 3: Field examples of the Boucaut Volcanics. a) flow banded rhyolite; b) Flow banded

147 rhyolite. Fresh undeformed pod surrounded by foliated equivalent (Sample 050220-12); c) banded 148 intermediate volcanic; d) flow banded or folded volcanic

149 Table 1: Sample descriptions, locations and analytical methods applied in this study.

\begin{tabular}{|l|l|l|l|l|}
\hline Sample & Description & $\begin{array}{l}\text { Analytical } \\
\text { methods }\end{array}$ & Latitude & Longitude \\
\hline $050219-01$ & $\begin{array}{l}\text { Anabama Mine. Metabasalt chips from RC } \\
\text { drilling collar. Strong foliation, silicified, sericite }\end{array}$ & WR & - & - \\
\hline $050219-03$ & $\begin{array}{l}\text { Boucaut volcanics type section. Fresh basalt } \\
\text { with vesicles filled with epidote }\end{array}$ & WR & -32.799685 & 140.295644 \\
\hline $050220-01$ & Boucaut volcanics type section & WR & -32.799685 & 140.295644 \\
\hline $050220-02$ & Boucaut volcanics type section & WR & -32.799685 & 140.295644 \\
\hline $050220-03$ & Boucaut volcanics type section & WR & -32.799685 & 140.295644 \\
\hline $050220-04$ & Boucaut volcanics type section & WR & -32.799685 & 140.295644 \\
\hline $050220-05$ & Boucaut volcanics type section & WR & -32.799685 & 140.295644 \\
\hline
\end{tabular}




\begin{tabular}{|l|l|l|l|l|}
\hline $050220-06$ & Boucaut volcanics type section & -32.799685 & 140.295644 \\
\hline $050220-07$ & Boucaut volcanics type section & WR & -32.799685 & 140.295644 \\
\hline $050220-08$ & Boucaut volcanics type section & WR & -32.799685 & 140.295644 \\
\hline $050220-10$ & Boucaut felsic volcanic & WR & -32.808832 & 140.300485 \\
\hline $050220-11$ & Boucaut felsic volcanic - foliated 309/73 & WR & -32.808832 & 140.300485 \\
\hline $050220-12$ & $\begin{array}{l}\text { Boucaut felsic volcanic. Fresh undeformed pod } \\
\text { surrounded by foliated equivalent }\end{array}$ & $\begin{array}{l}\text { WR + } \\
\text { geochronology }\end{array}$ & -32.809520 & 140.300800 \\
\hline $050220-13$ & Boucaut felsic volcanic - tuff? & WR & -32.825849 & 140.301249 \\
\hline $050220-14$ & Rhyolite with flow banding bedding 179/75 & WR & -32.825895 & 140.301409 \\
\hline $050220-15$ & Rhyolite with flow banding bedding & WR & -32.825258 & 140.302055 \\
\hline $050220-16$ & Rhyolite. Glassy K-spar rich & WR & -32.797221 & 140.329893 \\
\hline $050220-17$ & $\begin{array}{l}\text { Meta basalt chips from drillcore collar CRD15. } \\
\text { Some chalcopyrite mineralisation }\end{array}$ & WR & -32.815613 & 140.355403 \\
\hline $050220-18$ & $\begin{array}{l}\text { Rhyolite. Round clasts? K-spar rind, flow } \\
\text { banding. Bedding 335/71 }\end{array}$ & WR & -32.842648 & 140.285837 \\
\hline $050221-01$ & $\begin{array}{l}\text { Rhyolite with flow banding bedding. Foliation } \\
\text { and crenulation in parts. Bedding 335/85 }\end{array}$ & WR & -32.870726 & 140.168623 \\
\hline $050221-02$ & $\begin{array}{l}\text { Cronje Dam prospect Cu. Malachite along } \\
\text { foliation }\end{array}$ & WR & -32.865131 & 140.160146 \\
\hline
\end{tabular}

$151 \quad 3.2$ Zircon U-Pb geochronology and trace element geochemistry

152 Separated zircons from sample 050220-12 are generally euhedral with preserved facets and

153 pyramidal terminations. Most zircons are either banded or have concentric oscillatory zoning in

$154 \mathrm{CL}$ images (Figure 4). Forty-four U-Pb and trace element analyses were obtained from 41

155 zircons, of which 39 are within $10 \%$ of concordance and 29 are within $5 \%$ of concordance

156 (Figure 5). The 29 analyses within $5 \%$ concordance yield a ${ }^{206} \mathrm{~Pb} /{ }^{238} \mathrm{U}$ weighted average age of

$157788 \pm 6 \mathrm{Ma}(\mathrm{MSWD}=1.08)$, which we interpret as the crystallisation age of this sample. A

$158{ }^{207} \mathrm{~Pb} /{ }^{206} \mathrm{~Pb}$ weighted average of the same analyses yielded an age of $786 \pm 13 \mathrm{Ma}(\mathrm{MSWD}=$

159 0.29). 


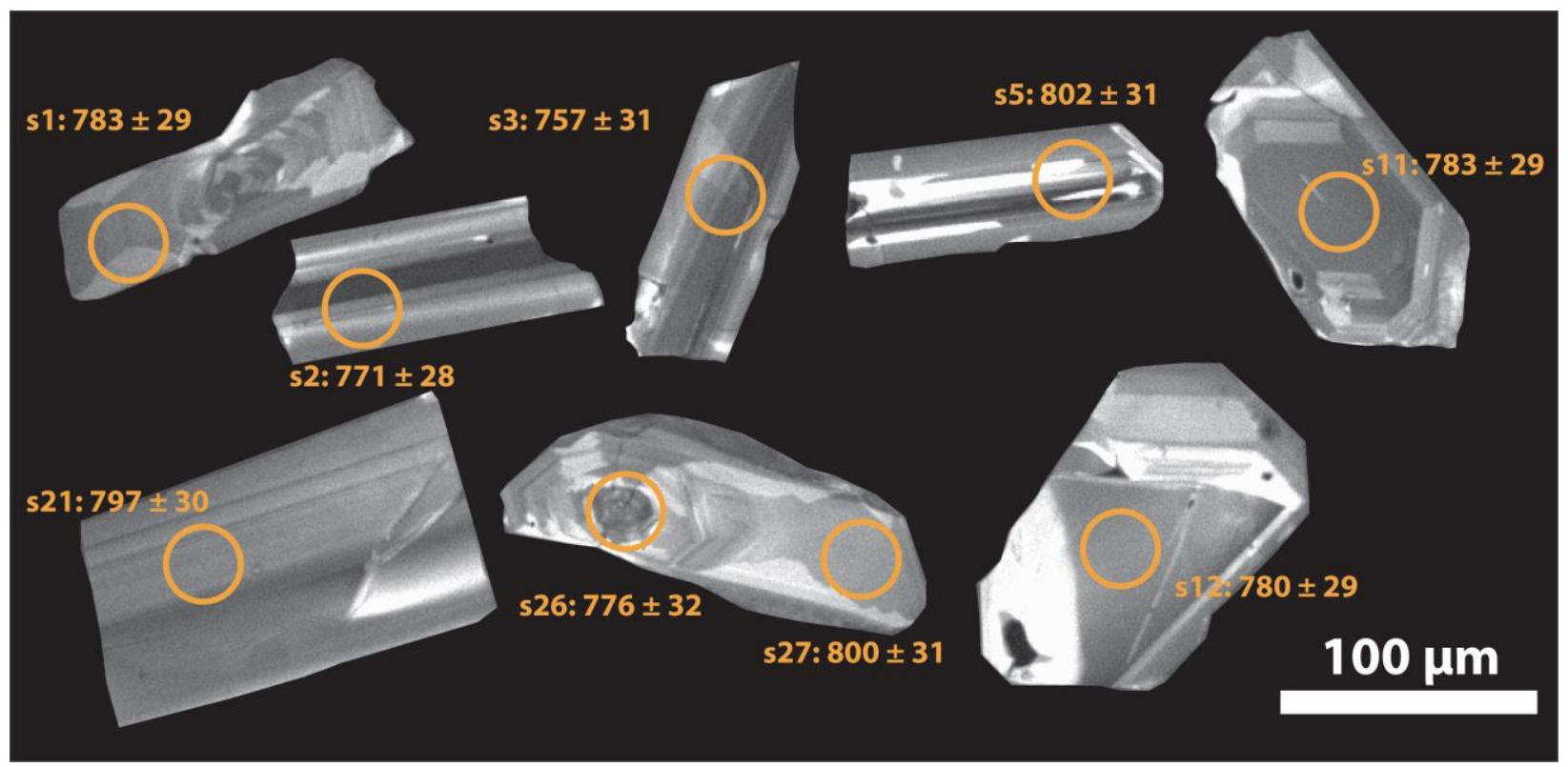

161 Figure 4: Examples of CL images for analysed zircons.
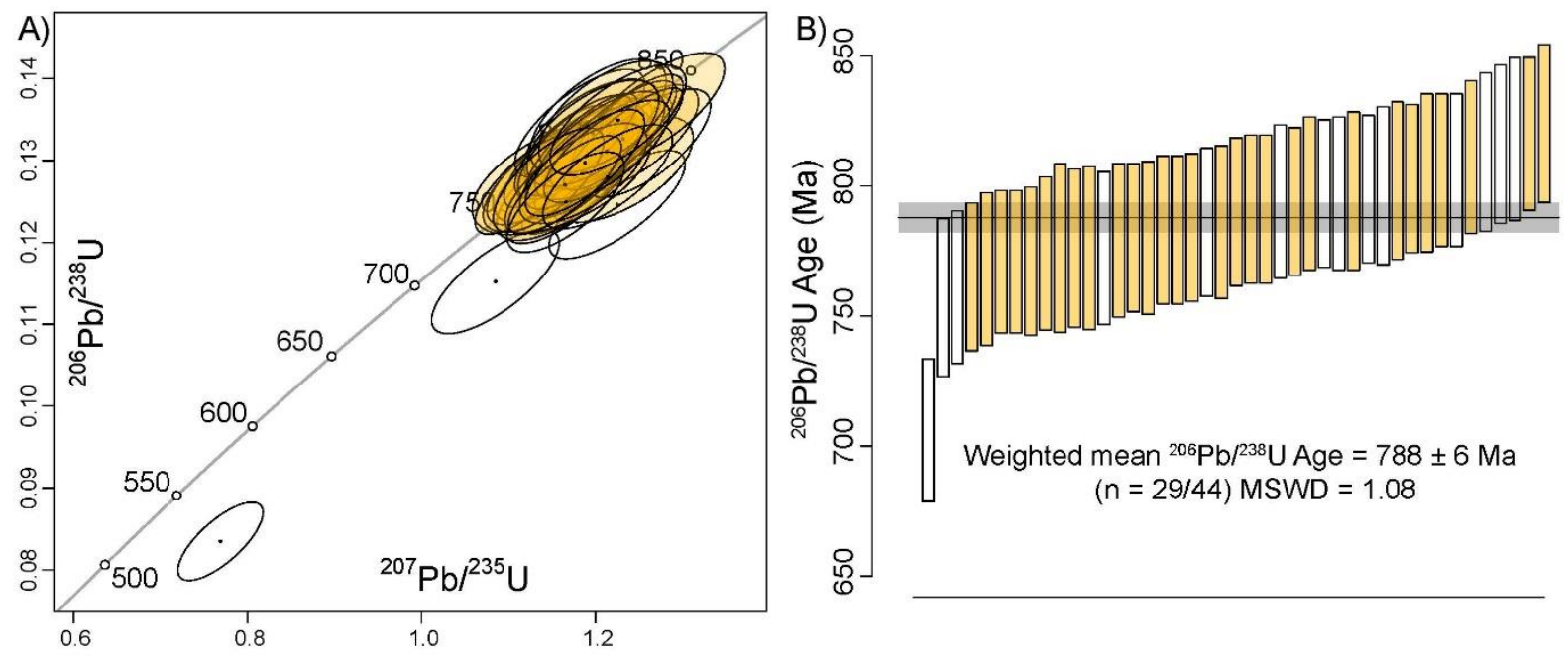

Figure 5: a) Conordia plot of $U-P b$ data, data within 5\% of concordance are included in age calculations (orange ellipses), and excluded data are interpreted as Pb-loss (white ellipses); b) Weighted average plot of the same data shown in (a). Plots and data produced using IsoplotR

166 (Vermeesch, 2018).

167 Trace element profiles from analyses that are within 10\% of concordance are shown in Figure 6 168 along with their $\mathrm{Th} / \mathrm{U}$ ratios. Zircons show $\mathrm{Th} / \mathrm{U}$ values between 0.5 and 1.2 that are consistent 
169 with igneous zircons (Belousova, Griffin, O'Reilly, \& Fisher, 2002). The majority of near

170 concordant zircon divide into two coupled Th/U and REE populations (Figure 6). One population

171 has $\mathrm{Th} / \mathrm{U}$ ratios $>0.8$, elevated rare earth elements and moderate positive $\mathrm{Ce}$ anomalies. The

172 second population has Th/U ratios $<0.8$ and a pronounced positive Ce anomaly. Both

173 populations have moderate negative Eu anomalies and positive medium to high rare earth

174 element gradients. The negative Eu anomaly can be caused by the presence of plagioclase in

175 the magma that the zircon grew in, and/or by a reducing magma. The latter possibility is

176 discounted as a positive Ce anomaly is a sign of an oxidising magma (Trail, Watson, \& Tailby,

177 2012). Additionally, Kirkland, Smithies, Taylor, Evans, and McDonald (2015) showed that Th/U

178 ratios positively correlate with temperature in a cooling fractionating magma due to the

179 preferential magma depletion of $U$ as the magma cools. We use these observations to suggest

180 that our analysed zircons reflect growth in a cooling fractionating magma chamber that was

181 becoming progressively more oxidized as it cooled.

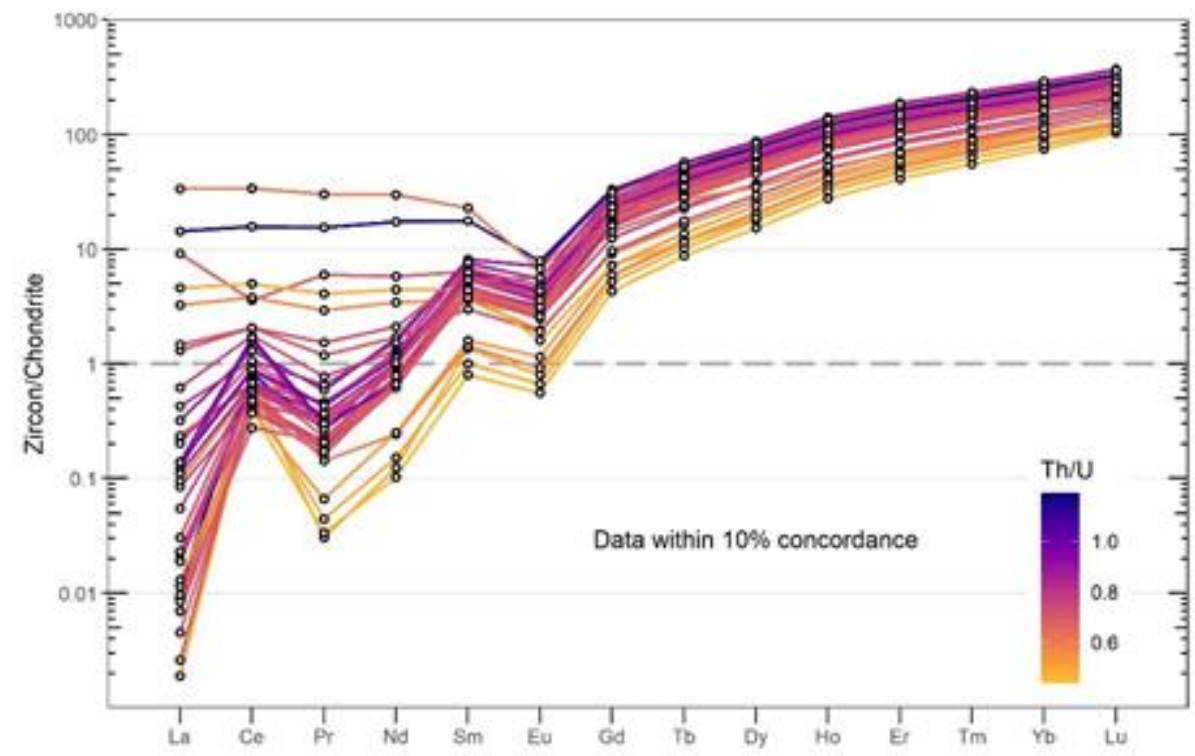

183 Figure 6: Trace element profile of zircons within 10\% concordance ( $n=39 / 44)$, coloured by Th/U. 184 Normalised to Chondrite (Sun \& McDonough, 1989). 


\subsection{Whole-rock geochemistry}

186 Rock samples from the Boucaut Volcanics range from basaltic to rhyolitic compositions, with

$187 \mathrm{SiO}_{2}$ ranging from $45 \%$ to $79 \%$ (Figure $7 \mathrm{a}$ ). Around half of the samples plot within the rhyolite

188 field on a total alkali silica (TAS) diagram (Le Bas, Le Maitre, Streckeisen, Zanettin, \& Rocks, 189 1986), with the remaining samples plotting within the basalt, andesite and dacite fields. Samples 190 range from ferroan to magnesian.

191 On the REE diagram of sample/chondrite (Figure 7c), samples are enriched in LREE over 192 HREE, with some exhibiting a negative Eu anomaly indicating plagioclase fractionation.

193 On the sample/primitive mantle REE diagram, samples show a strong negative Sr anomaly, 194 which is more pronounced for the felsic samples. Samples show a strong positive $\mathrm{Pb}$ anomaly, 195 with this signature being more pronounced for mafic samples. 

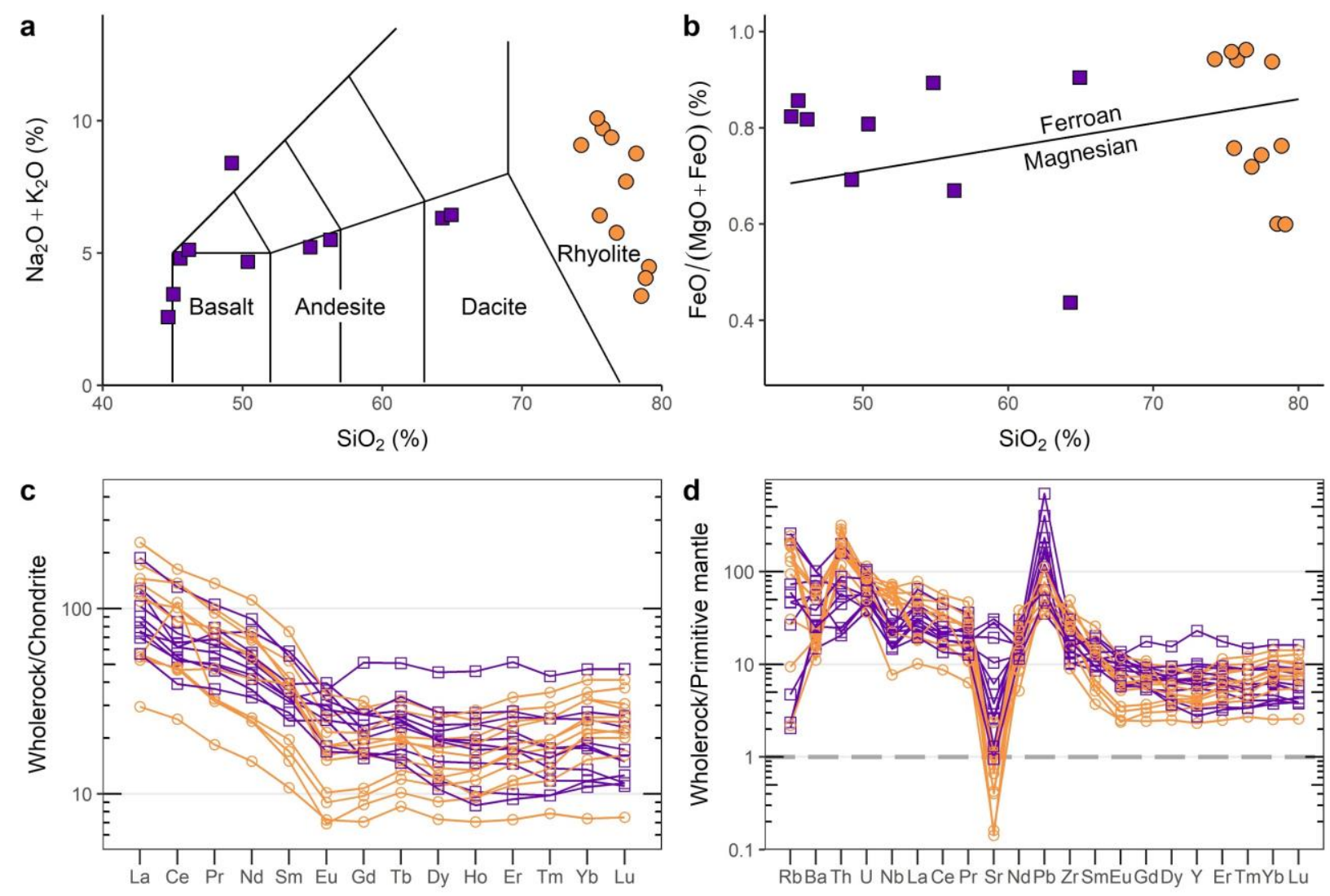

Boucaut Volcanics $\bigcirc$ Felsic $\left(\mathrm{SiO}_{2}>70 \%\right) \quad$ Mafic to intermediate $\left(\mathrm{SiO}_{2}<70 \%\right)$

Figure 7: Whole-rock geochemistry plots a) total Alkali vs. Silica plot after Le Bas et al., 1986; b) \& McDonough, 1989); d) Trace elements normalised to primitive mantle.

\section{DISCUSSION AND IMPLICATIONS}

201 Here we present a revised age for the eruption of the Boucaut Volcanics at $788 \pm 6$ Ma along 202 with whole-rock geochemistry for a range of samples from the Boucaut Volcanics. This age is 203 older than a poorly documented age of $777 \pm 7$ Ma that was based on a personal

204 communication with no associated isotopic data. The new age presented here provides 
205 important constraints on early rifting in the Adelaide Rift Complex, and provides a piercing point 206 for plate tectonic reconstructions. The revised age of $788 \pm 6 \mathrm{Ma}$ constrains the onset of the 207 third phase of rifting in the Adelaide Rift Complex (Figure 2c) to be as early as $788 \pm 6 \mathrm{Ma}$, 208 earlier than previously suggested (Preiss, 2000), but more consistent with kinematic constraints 209 on the timing of the Australia-Laurentia rift-drift transition as central Rodina broke up (Merdith et 210 al. 2017b).

211 This new age of the Boucaut Volcanics constrains the base of the Burra Group to $788 \pm 6 \mathrm{Ma}$. 212 The underlying Callanna Group, has a reported maximum age of $802 \pm 10 \mathrm{Ma}$ (Fanning et al., 213 1986), which, however, is only documented in an abstract with no isotopic data. The Callanna 214 Group appears not to contain the ca. 810 Ma Bitter Springs carbon isotope anomaly (Macdonald 215 et al. 2010; Stueken et al. 2019), which may be used as a minimum age constraint. Although 216 more work needs to confirm that the basin waters had compositions similar to the 217 contemporaneous ocean waters. Our new data now provide a revised minimum age for the 218 deposition of the Callanna Group of $788 \pm 6 \mathrm{Ma}$.

219 Several intrusive and extrusive magmatic suites are present within the Adelaide Superbasin. 220 Due to the scarcity of robust age constraints, these have been challenging to place within a 221 tectonostratigraphic framework, and to correlate with other units across the region. The 222 Kooringa Member within the Skillogallee Dolomite contains an intrusive porphyry that has been 223 data at $794 \pm 4 \mathrm{Ma}$ (Preiss et al., 2009). This is within uncertainty of the Boucaut Volcanics and 224 may represent an intrusive equivalent. 


\section{ACKNOWLEDGEMENTS}

226

227

228

229

230

231

232

233

234

235

236

237

238

239

240

241

242

243

244

245

246

247

248

249

250

251

252

253

254

255

256

257

258

259

260

Jarred Lloyd and Claire Wade are thanked for providing regional overview data and context.

ASC acknowledged the MinEx CRC and his contribution forms MinEx CRC output \#2020/xx.

Sarah Gilbert and Ben Wade at Adelaide Microscopy are thanked for help obtaining analytical

data.

\section{REFERENCES}

Belousova, E., Griffin, W. L., O'Reilly, S. Y., \& Fisher, N. (2002). Igneous zircon: trace element composition as an indicator of source rock type. Contributions to mineralogy and petrology, 143(5), 602-622.

Burrett, C., \& Berry, R. (2000). Proterozoic Australia-Western United States (AUSWUS) fit between Laurentia and Australia. Geology, 28(2), 103-106.

Calver, C. (1998). Isotope stratigraphy of the Neoproterozoic Togari Group, Tasmania. Australian Journal of Earth Sciences, 45(6), 865-874.

Compston, W., Crawford, A., \& Bofinger, V. (1966). A radiometric estimate of the duration of sedimentation in the Adelaide Geosyncline, South Australia. Journal of the Geological Society of Australia, 13(1), 229-276.

Dalziel, I. W. (1991). Pacific margins of Laurentia and East Antarctica-Australia as a conjugate rift pair: Evidence and implications for an Eocambrian supercontinent. Geology, 19(6), 598-601.

Dehler, C., Gehrels, G., Porter, S., Heizler, M., Karlstrom, K., Cox, G., . . Timmons, M. (2017). Synthesis of the 780-740 Ma Chuar, Uinta Mountain, and Pahrump (ChUMP) groups, western USA: implications for Laurentia-wide cratonic marine basins. Bulletin, 129(5-6), 607-624.

Drexel, J., Preiss, W., \& Parker, A. (1993). The geology of South Australia, vol. 1. The Precambrian: South Australia Geological Survey. Bulletin, 54, 242.

Fanning, C. (1989). U-Pb dating of the Boucaut Volcanics and Bendigo Granite. Amdel report G, 7948.

Fanning, C., Ludwig, K., Forbes, B., \& Preiss, W. (1986). Single and multiple grain U-Pb zircon analyses for the early Adelaidean Rook Tuff, Willouran Ranges, South Australia. Paper presented at the Geological Society of Australia Abstracts.

Forbes, B. G. (1978). The Boucaut Volcanics. The Geological Survey of South Australia Quarterley Geological Notes(65), 6-10.

Frost, B. R., \& Frost, C. D. (2008). A geochemical classification for feldspathic igneous rocks. Journal of petrology, 49(11), 1955-1969.

Hoffman, P. F. (1991). Did the breakout of Laurentia turn Gondwanaland inside-out? Science, 252(5011), 1409-1412. 
Hoffman, P. F., Abbot, D. S., Ashkenazy, Y., Benn, D. I., Brocks, J. J., Cohen, P. A., ... Erwin, D. H. (2017). Snowball Earth climate dynamics and Cryogenian geology-geobiology. Science Advances, 3(11), e1600983.

Jackson, S. E., Pearson, N. J., Griffin, W. L., \& Belousova, E. A. (2004). The application of laser ablation-inductively coupled plasma-mass spectrometry to in situ U-Pb zircon geochronology. Chemical Geology, 211(1), 47-69.

Karlstrom, K. E., Harlan, S. S., Williams, M. L., McLelland, J., Geissman, J. W., \& Ahall, K.-I. (1999). Refining Rodinia: Geologic evidence for the Australia-western US connection in the Proterozoic. GSA Today, 9(10), 1-7.

Kirkland, C., Smithies, R., Taylor, R., Evans, N., \& McDonald, B. (2015). Zircon Th/U ratios in magmatic environs. Lithos, 212, 397-414.

Le Bas, M., Le Maitre, R., Streckeisen, A., Zanettin, B., \& Rocks, I. S. o. t. S. o. I. (1986). A chemical classification of volcanic rocks based on the total alkali-silica diagram. Journal of petrology, 27(3), 745-750.

Le Heron, D. P., Cox, G., Trundley, A., \& Collins, A. S. (2011). Two Cryogenian glacial successions compared: Aspects of the Sturt and Elatina sediment records of South Australia. Precambrian Research, 186(1-4), 147-168.

Li, Z.-X., Zhang, L., \& Powell, C. M. (1995). South China in Rodinia: part of the missing link between Australia-East Antarctica and Laurentia? Geology, 23(5), 407-410.

Lloyd, J. C., Blades, M. L., Counts, J. W., Collins, A. S., Amos, K. J., Wade, B. P., . . Shahin, S. (2020). Neoproterozoic Geochronology and Provenance of the Adelaide Superbasin. Precambrian Research, 105849.

Mahon, R. C., Dehler, C. M., Link, P. K., Karlstrom, K. E., \& Gehrels, G. E. (2014). Detrital zircon provenance and paleogeography of the Pahrump Group and overlying strata, Death Valley, California. Precambrian Research, 251, 102-117.

Merdith, A. S., Collins, A. S., Williams, S. E., Pisarevsky, S., Foden, J. D., Archibald, D. B., . . Plavsa, D. (2017). A full-plate global reconstruction of the Neoproterozoic. Gondwana Research, 50, 84-134.

Merdith, A. S., Williams, S. E., Müller, R. D., \& Collins, A. S. (2017). Kinematic constraints on the Rodinia to Gondwana transition. Precambrian Research, 299, 132-150.

Milton, J. E., Hickey, K. A., Gleeson, S. A., \& Friedman, R. M. (2017). New U-Pb constraints on the age of the Little Dal Basalts and Gunbarrel-related volcanism in Rodinia. Precambrian Research, 296, 168-180.

Moores, E. (1991). Southwest US-East Antarctic (SWEAT) connection: a hypothesis. Geology, 19(5), 425-428.

Mulder, J. A., Berry, R. F., Halpin, J. A., Meffre, S., \& Everard, J. L. (2018). Depositional age and correlation of the Oonah Formation: refining the timing of Neoproterozoic basin formation in Tasmania. Australian Journal of Earth Sciences, 65(3), 391-407. doi:10.1080/08120099.2018.1426629

Paton, C., Hellstrom, J., Paul, B., Woodhead, J., \& Hergt, J. (2011). lolite: Freeware for the visualisation and processing of mass spectrometric data. Journal of Analytical Atomic Spectrometry, 26(12), 2508-2518.

Powell, C. M., Preiss, W., Gatehouse, C., Krapez, B., \& Li, Z.-X. (1994). South Australian record of a Rodinian epicontinental basin and its mid-Neoproterozoic breakup ( $700 \mathrm{Ma})$ to form the Palaeo-Pacific Ocean. Tectonophysics, 237(3-4), 113-140.

Preiss, W. (2000). The Adelaide Geosyncline of South Australia and its significance in Neoproterozoic continental reconstruction. Precambrian Research, 100(1-3), 21-63. 
Sláma, J., Košler, J., Condon, D. J., Crowley, J. L., Gerdes, A., Hanchar, J. M., . . Norberg, N. (2008). Plešovice zircon-a new natural reference material for $\mathrm{U}-\mathrm{Pb}$ and $\mathrm{Hf}$ isotopic microanalysis. Chemical Geology, 249(1), 1-35.

Sun, S.-S., \& McDonough, W.-S. (1989). Chemical and isotopic systematics of oceanic basalts: implications for mantle composition and processes. Geological Society, London, Special Publications, 42(1), 313-345.

Trail, D., Watson, E. B., \& Tailby, N. D. (2012). Ce and Eu anomalies in zircon as proxies for the oxidation state of magmas. Geochimica et Cosmochimica Acta, 97, 70-87.

Vermeesch, P. (2018). IsoplotR: A free and open toolbox for geochronology. Geoscience Frontiers, 9(5), 1479-1493.

Wingate, M. T., Campbell, I. H., Compston, W., \& Gibson, G. M. (1998). Ion microprobe U-Pb ages for Neoproterozoic basaltic magmatism in south-central Australia and implications for the breakup of Rodinia. Precambrian Research, 87(3-4), 135-159.

Wingate, M. T., Pisarevsky, S. A., \& Evans, D. A. (2002). Rodinia connections between Australia and Laurentia: no SWEAT, no AUSWUS? Terra Nova, 14(2), 121-128. 